\title{
Rancang Bangun Sistem Informasi Manajemen Mutu Perusahaan Menggunakan Framework Laravel dan Materialize (Studi Kasus : Bagian Pengendalian Dokumen PT. Pura Barutama Divisi Boxindo, Kudus)
}

\author{
Stefan Fernando \\ Andeka Rocky Tanaamah \\ Agustinus Fritz Wijaya
}

Program Studi Sistem Informasi, Fakultas Teknologi Informasi, Universitas Kristen Satya Wacana, Salatiga 50711, Indonesia

Email:

682013024@student.uksw.edu, atanaamah@staff.uksw.edu, agustinus.wijaya@staff.uksw.edu

\begin{abstract}
Quality management is one of important aspects in the company for keep the quality of service and gaining trust from its customers, however there are some problems in monitoring the quality and performance audit result, audit schedule distribution, and ISO 9001:2008 document distribution. Therefore it needs to be managed with an integrated database system. The Purpose of this research is to design and build information system of quality management to help monitoring the quality and performance audit result, audit schedule distribution, and helps the management of ISO 9001:2008 document. System development model in this research used prototyping method. The test results using Black Box Testing Methods and interview with users indicated that the developed Information System of Quaity Management (ISQM) has been functioning in accordance with the expected functional and operational requirements.
\end{abstract}

Keywords: Information System of Quality Management, design and build information system, ISO 9001:2008

\section{ABSTRAKSI}

Manajemen mutu merupakan suatu hal yang penting didalam perusahaan dalam mempertahankan kualitas layanan dan mendapatkan kepercayaan dari para pelanggannya, namun pada pelaksanaannya terdapat kendala ketika melakukan monitoring capaian mutu dan temuan audit, pendistribusian jadwal audit serta pendistribusian dokumen ISO 9001:2008, oleh karena itu data-data tersebut perlu dikelola dengan sistem database yang terintegrasi. Penelitian ini bertujuan merancang aplikasi sistem informasi manajemen mutu untuk membantu dalam melakukan monitoring capaian mutu dan temuan audit, pendistribusian jadwal audit, serta membantu dalam pengelolaan dokumen ISO 9001:2008. Identifikasi kebutuhan pengguna dan sistem dilakukan melalui wawancara di bagian pengendali dokumen. Model pengembangan sistem dalam penelitian ini menggunakan metode Prototyping. Hasil pengujian menggunakan Metode Black Box Testing dan wawancara dengan pengguna menunjukkan bahwa Sistem Informasi Manajemen Mutu Box (SIMMB) yang dikembangkan telah berfungsi sesuai dengan kebutuhan fungsional dan operasional yang diharapkan.

Kata kunci: Sistem Informasi Manajemen Mutu, Rancang Bangun Sistem Informasi, ISO 9001:2008 